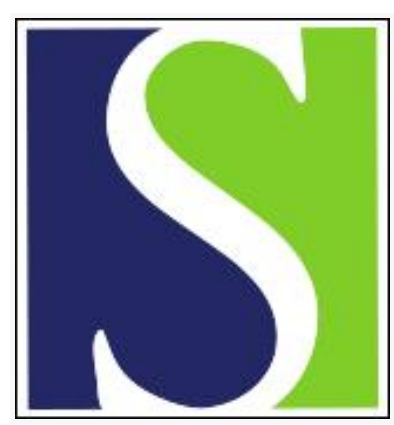

Scand J Work Environ Health 1997;23(5):378-384

https://doi.org/10.5271/sjweh.235

Issue date: Oct 1997

Job adjustment as a means to reduce sickness absence during pregnancy

by Strand K, Wergeland E, Bjerkedal T

The following articles refer to this text: 2013;39(4):321-323;

2015;41(2):184-193; 2015;41(4):397-406; 2020;46(1):60-68

Key terms: pregnancy; protective legislation; work

This article in PubMed: www.ncbi.nlm.nih.gov/pubmed/9403469

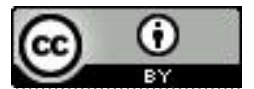




\title{
Job adjustment as a means to reduce sickness absence during pregnancy
}

\author{
by Kitty Strand, MD, ${ }^{1}$ Ebba Wergeland, MD, ${ }^{1}$ Tor Bjerkedal, $M D^{1}$
}

\begin{abstract}
Strand $K$, Wergeland $E$, Bjerkedal $T$. Job adjustment as a means to reduce sickness absence during pregnancy. Scand J Work Environ Health 1997;23(5):378-84.
\end{abstract}

Objectives This study examined the effect of job adjustment on sickness absence during pregnancy and also determined the conditions under which such adjustments are obtained.

Methods Data were derived from a nationally representative survey on work conditions during pregnancy in Norway in 1989. For employees $(\mathrm{N}=2713)$ remaining in the same job throughout pregnancy, the percentage of women on sick leave immediately before delivery was determined according to the need for job adjustment and the obtainment of job adjustment. Those obtaining job adjustment were grouped according to workplace size, labor-market sector, co-worker gender, educational level, work schedules, weekly workhours, children under 16 years of age in the household, and age.

Results All told, 1691 women (62.3\%) needed job adjustment, among whom 936 (55.4\%) obtained such adjustment. The proportions of those on sick leave before delivery were $45.2 \%$ for "no need", $67.9 \%$ for "need - adjustment obtained", and $79.2 \%$ for "need - adjustment not obtained". In the last category, the difference (versus "adjustment obtained") constituted $44.5 \%$ of the weeks lost because of sickness absence in the last half of pregnancy. The odds ratio (OR) for obtaining job adjustment was larger for workplaces with more than 50 employees (OR 1.4) and smaller for jobs with work schedules other than daytime or shift work (OR 0.5$)$ and also for women living with children under 16 years of age (OR 0.8).

Conclusions Job adjustment is associated with reduced sickness absence during pregnancy. Further studies should explore workplace characteristics that make it difficult to obtain such adjustments, as required by law.

Key terms pregnancy, protective legislation, work.

High levels of sickness absence during pregnancy have been reported from several countries during the last decade $(1-5)$. Both the rate and duration are positively associated with strenuous work conditions. However, pregnancy-related sickness absence is high even in occupations with low rates of sickness absence for nonpregnant women (6).

In several European countries, protective legislation requires that employers adjust work conditions according to the needs of pregnancy $(7,8)$. Reduced risk of sickness absence during pregnancy would be expected as a result of such adjustment. So far, few studies have addressed this issue directly. Saurel-Cubizolles \& Kaminski (1) found reduced sickness absence rates for pregnant employees reporting that job adjustment had been implemented, and Mamelle et al (9) found reduced risk of sickness absence in a group obtaining reduced weekly workhours throughout pregnancy. The reported variation in pregnancy-related sickness absence rates between occupations with similar work conditions (6) might partly result from differences in the job adjustment obtained.

A study from France and Italy examining compliance with protective maternity legislation found better compliance in the public sector of the labor market (versus the private) and for qualified workers (versus unqualified) (10). A survey of British employers about arrangements of alternative work for pregnant employees found increased alteration rates in the public sector (versus the private) and in large workplaces (versus small) (11).

The aims of this study were to use a representative sample of women giving birth in Norway in 1989 to determine whether pregnancy-related job adjustment is associated with reduced risk of sick leave before delivery and to study the conditions under which such adjustments are obtained in the Norwegian labor market.

1 Department of Preventive Medicine, Institute of General Practice and Community medicine, University of Oslo, Oslo, Norway.

Reprint requests to: Dr Kitty Strand, Department of Preventive Medicine, Institute of General Practice and Community Medicine, University of Oslo, POB 1130 Blindern, 0317 Oslo, Norway. 


\section{Subjects and methods}

\section{Study population}

The study was based on data from a national crosssectional survey called "Pregnancy and Work" that was conducted in Norway from 16 October to 26 November 1989. Of the 6235 women registered by Statistics Norway as having given birth in the period in question, 5438 $(87.2 \%)$ completed an extensive questionnaire after delivery, while still in the maternity ward (12). The respondents were representative of women giving birth in Norway in 1989, except for an underrepresentation of women with non-Nordic citizenship and women with low or no income of their own (13).

Among the 5438 respondents, 4205 were in paid employment at the beginning of pregnancy, of whom 3929 were employees. During pregnancy, 836 of the employees left their original employment, mainly because their work contracts ended (50.2\%). Leaving work was evenly distributed throughout pregnancy. Among the 3093 employees remaining in the same job throughout pregnancy, all data on leaving work were known for 2713 $(87.7 \%)$. The nonrespondents did not differ from the 2713 with regard to background variables, occupational exposure, or job adjustment.

\section{Variables}

The job adjustment variables were based on the question "Were work conditions changed during pregnancy so that they suited you better as pregnant?" As the exposure variable in relation to sickness certification, a job adjustment variable with 3 categories was defined: "no need for adjustment", "need - adjustment obtained", and "need - adjustment not obtained". For association with conditions influencing job adjustment, the proportion obtaining adjustment among those in need was employed as the outcome variable. This proportion was calculated as the percentage obtaining job adjustment among the total number in need of job adjustment.

Sick leave before delivery was defined as an affirmative answer to the question: "Did the (last) sick leave continue until delivery so that you were not back at work before you gave birth or started your maternity leave?" The duration of the last sick leave before delivery was calculated as (weeks of last sick leave + (date of maternity leave / date of delivery) / 7), and it was based on answers to the following questions: "How many weeks did this episode last?" (weeks). "Do you have maternity leave now, and, if so, when did it start?" (yes or no, date); "When did you give birth?" (date).

The questions on sick leave were tested for reliability in a sample of 40 women answering the questionnaire twice (postpartum in the hospital and 8 to 10 weeks later). The reliability was high for all the questions, the kappa coefficients being between 0.9 and 1 . The questions on maternity leave and job adjustment were not pretested in their final version.

The independent variables examined for association with obtaining job adjustment were partly chosen on the basis of earlier studies. They included occupation, educational level, labor-market sector, and size of the workplace $(10,11)$. In addition, the following variables presumed to affect adjustment practice were included: gender of co-workers, work schedules, weekly workhours, children under 16 years of age in the woman's household, and age. The questions referred to the time the woman discovered she was pregnant. The questionnaire data on the labor-market sector (private or public) and children under 16 years of age (yes or no) were pretested for reliability, and the kappa coefficients was 0.9 for both.

The questions on size of worksite $(\leq 10$ employees, $11-50$ employees, or $>50$ employees), gender of coworkers (co-workers mostly women, equal numbers of women and men, or mostly men), work schedule [daytime work or shift work or other type of work schedule (evening work, night work, no fixed schedule)] and weekly workhours $(<35$ or $\geq 35$ ) were not pretested in their final version.

Occupation was classified on the basis of questions similar to those asked in the Labor Market Survey of Statistics Norway, and the coding was performed by trained personnel at Statistics Norway, according to the standard classification used in Norwegian official statistics based on the International Standard Classification of Occupations (ISCO) (14).

Questionnaire data on age (completed years at the end of 1989) and education (highest completed education according to duration) agreed well with those of the same population in the Norwegian medical birth register and Statistics Norway.

\section{Data analyses}

The rates for the subjects' leaving work because of sickness were computed for each category of job adjustment. Sickness absence for the subjects needing but not obtaining adjustment was compared with that of the subjects needing and obtaining adjustment for an estimate of the excess number of weeks. For every week between 20 and 3 weeks before delivery, the difference in the percentages between the 2 categories was calculated. In the groups needing but not obtaining adjustment $(\mathrm{N}=755)$, the total number on sick leave and the number represented by the difference between this group and that needing and obtaining adjustment was calculated for each week and added for the total number. Sick leave excess was calculated as the number of weeks of difference as the percentage of the total number of weeks.

To assess the influence of recall bias, a second analysis of the association between job adjustment and the 
rate of sick leave was performed. On the basis of the answers from the women not leaving work on sick leave $(\mathrm{N}=963)$, the occupations were divided into a group labeled "high adjustment rates" (ie, occupations for which the percentage reporting to have obtained job adjustment was higher than the mean) and a group labeled "low adjustment rates" (ie, occupations for which the percentage reporting to have obtained job adjustment was equal to or lower than the mean). The rates for sick leave in the 2 occupational groups were then compared.

Among those in need of job adjustment, the proportion obtaining adjustment was calculated along with the 95\% confidence intervals (15) for each level of the independent variables. As there was a very large nonresponse

Table 1. Categories of job adjustment and the proportion of women having left work on sick leave before delivery.

\begin{tabular}{|c|c|c|c|c|c|}
\hline \multirow[t]{2}{*}{$\begin{array}{l}\text { Categories of job } \\
\text { adjustment }\end{array}$} & \multicolumn{2}{|c|}{ Total cohort } & \multicolumn{3}{|c|}{$\begin{array}{c}\text { Subcohort of those } \\
\text { who left work } \\
\text { on sick leave } \\
\text { before delivery }\end{array}$} \\
\hline & $N$ & $\%$ & $N$ & Percent & $95 \% \mathrm{Cl}$ \\
\hline No need & 963 & 35.5 & 435 & 45.2 & $42.0-48.4$ \\
\hline Need & 1691 & 62.3 & 1233 & 72.9 & $70.8-75.0$ \\
\hline $\begin{array}{l}\text { Adjustment obtained } \\
\text { Adjustment not obtained }\end{array}$ & $\begin{array}{l}936 \\
755\end{array}$ & $\begin{array}{l}55.4 \\
44.6\end{array}$ & $\begin{array}{l}635 \\
598\end{array}$ & $\begin{array}{l}67.9 \\
79.2\end{array}$ & $\begin{array}{l}65.0-70.8 \\
76.3-82.1\end{array}$ \\
\hline Unknown & 59 & 2.2 & & & \\
\hline Total & 2713 & 100.0 & & 63.4 & \\
\hline
\end{tabular}

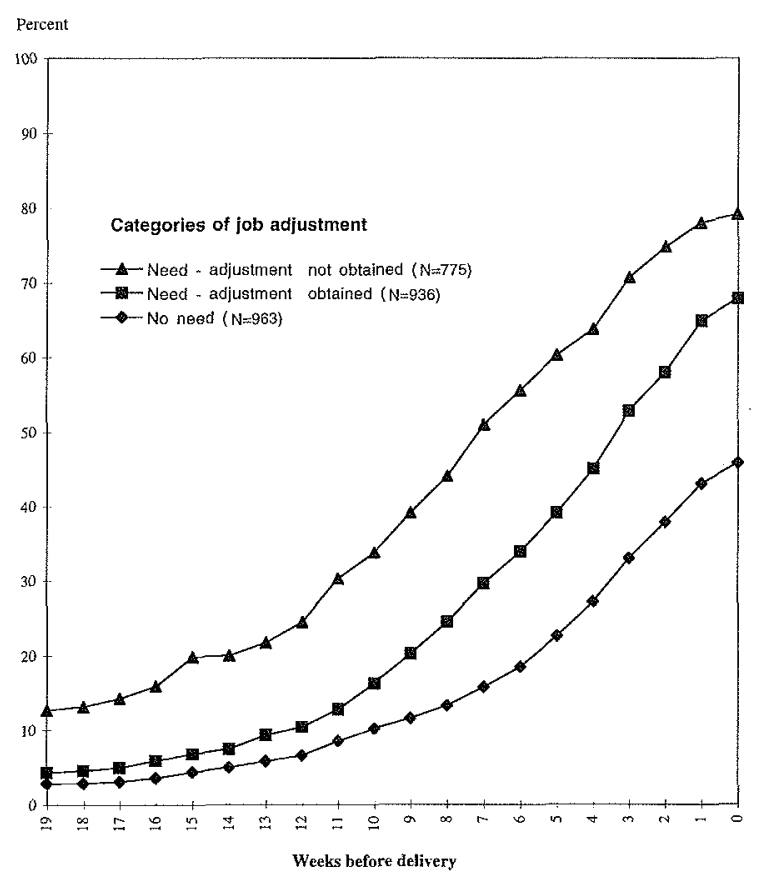

Figure 1. Cumulative percentage of the women $(N=2713)$ who left work on sick leave before delivery according to categories of job adjustment. group for the labor sector question, we repeated the analyses by dividing the population into a private and a public industrial division according to occupation (16). The adjusted odds ratios with their $95 \%$ confidence intervals were calculated by entering the independent variables (size of workplace, sector of the labor market, gender of co-workers, work schedules, educational level, weekly workhours, children under 16 years of age, and age) simultaneously in a logistic regression model with the proportion obtaining adjustment as the dependent variable (17). The variable children under 16 years of age was examined for interaction with all the other independent variables.

Analyses were performed with the SPSS program package (18).

\section{Ethics}

The protocol for the survey "Pregnancy and Work" was approved by the regional ethics committee (region II, Oslo).

\section{Results}

Of the 2713 pregnant employees, 1691 (62.3\%) reported that they needed job adjustment (table 1). Among those in need, adjustment was obtained by $55.4 \%$ (936 of 1691). The lowest rate of sick leave $(45.2 \%)$ was found for those not in need of job adjustment, followed by that for women having obtained adjustment (67.9\%) (table 1). Women in need but not obtaining adjustment had the highest sick leave rate $(79.2 \%)$ and left work on sick leave earlier in pregnancy than did the other women (figure 1). The difference between this category and those obtaining adjustment represented 1984.2 weeks or $44.5 \%$ of all weeks on sick leave in the latter half of pregnancy. When the rates for sick leave were computed for the occupational groups "high adjustment" and "low adjustment", based on the answers from the women who did not leave work on sick leave, the results were $59.9 \%$ and $67.8 \%$, respectively (Pearson's chi square $17.10, \mathrm{df}=1$, $\mathrm{P}=0.00004$ ).

The need for job adjustment varied widely between occupations, from around $40 \%$ in office work to $80-$ $90 \%$ in work with heavy loads like nursing or manufacturing (table 2). Within most occupations, 50\% to $60 \%$ of those reporting a need for adjustment also obtained the needed adjustment. Low percentages were observed for teachers $(41.2 \%)$ and cleaners $(21.7 \%)$. A high percentage $(73.6 \%)$ was observed for postal and telecommunication workers (table 2).

In the bivariate analyses, the proportion of women whose tasks were adjusted increased with increasing size of the workplace and educational level and decreased with "other work schedules", part-time work, children in 
Table 2. Need for job adjustment and the proportion of women obtaining adjustment according to occupation. ( $95 \% \mathrm{Cl}=95 \%$ confidence interval)

\begin{tabular}{|c|c|c|c|c|c|}
\hline \multirow[t]{2}{*}{ Occupation ${ }^{\mathrm{a}}$} & \multirow[t]{2}{*}{ Number } & \multicolumn{2}{|c|}{ Need for job adjustment } & \multirow{2}{*}{$\begin{array}{c}\text { Proportion } \\
\text { obtaining } \\
\text { adjustment }\end{array}$} & \multirow[t]{2}{*}{$95 \% \mathrm{Cl}$} \\
\hline & & N & $\%$ & & \\
\hline $\begin{array}{l}\text { Technical, physical, humanistic } \\
\text { or artistic work }(0)\end{array}$ & 1030 & 679 & 65.9 & 54.1 & $50.4-57.8$ \\
\hline $\begin{array}{l}\text { Social work (02) } \\
\text { Nursing (04) } \\
\text { Teaching (06) }\end{array}$ & $\begin{array}{l}113 \\
425 \\
279\end{array}$ & $\begin{array}{r}52 \\
337 \\
165\end{array}$ & $\begin{array}{l}46.0 \\
79.3 \\
59.1\end{array}$ & $\begin{array}{l}55.8 \\
57.6 \\
41.2\end{array}$ & $\begin{array}{l}42.3-69.3 \\
52.2-62.8 \\
33.7-48.7\end{array}$ \\
\hline Administrative or executive work (1) & 98 & 38 & 38.8 & 47.4 & $31.5-63.3$ \\
\hline Clerical work (2) & 597 & 242 & 40.5 & 62.8 & $56.7-68.9$ \\
\hline Sales work (3) & 270 & 179 & 66.3 & 61.5 & $54.4-68.6$ \\
\hline Retail sales work (33) & 230 & 162 & 70.4 & 63.0 & $55.6-70.4$ \\
\hline Agricultural work (4) & 23 & 21 & 91.3 & 52.4 & $31.0-73.8$ \\
\hline Transport and communication work (6) & 108 & 80 & 74.1 & 66.3 & $55.9-76.7$ \\
\hline Postal and telecommunication work (67) & 73 & 53 & 72.6 & 73.6 & $61.6-85.6$ \\
\hline Manufacturing work $(7-8)$ & 164 & 143 & 87,2 & 55.2 & $49.6-60.8$ \\
\hline Service work (9) & 411 & 302 & 73.5 & 46.7 & $41.1-52.3$ \\
\hline $\begin{array}{l}\text { Hotel or restaurant work (91) } \\
\text { Cleaning work (93) }\end{array}$ & $\begin{array}{l}189 \\
101\end{array}$ & $\begin{array}{r}138 \\
69\end{array}$ & $\begin{array}{l}73.0 \\
68.3\end{array}$ & $\begin{array}{l}57.2 \\
21.7\end{array}$ & $\begin{array}{l}48.9-65.5 \\
12.0-31.4\end{array}$ \\
\hline Unknown & 12 & 7 & 58.3 & & \\
\hline Total & 2713 & 1691 & 62.3 & 55.4 & $53.0-57.8$ \\
\hline
\end{tabular}

the household, and age (table 3). The labor-market sector and the gender of co-workers were not associated with this proportion. When the analysis was repeated with the labor-market sector determined according to occupation, the proportion obtaining adjustment in the private and public sectors was $56.9 \%$ and $54.3 \%$ respectively; this finding supports the validity of the findings presented in table 3 .

When adjusted for the other variables by logistic regression (table 3), job adjustment was more frequently obtained in workplaces with more than 50 employees [odds ratio (OR 1.4)] and less frequently obtained for jobs with "other work schedules" (OR 0.5) and for women with children under 16 years of age in the household (OR 0.8). Educational level, weekly workhours, and age had no independent effect. No interactions were found between children under 16 years of age and the other independent variables.

\section{Discussion}

\section{Job adjustment and sickness absence}

Pregnancy-related job adjustment was associated with reduced risk of sickness absence in Norway in 1989 as in France in 1981 (1). The effect was substantial; for example, if a causal relationship is assumed and also if it is assumed that the 46276 employed women giving birth in Norway in 1989 (19) had the same work and adjustment patterns as the sample studied, more than 25000 weeks of sickness absence could have been avoided by providing job adjustment for those who needed it.

This is a very rough estimate. A difference in sick leave rates between those who obtain and those who do not obtain adjustment is already established during the first half of pregnancy, being $8.4 \%$ in the 20 th week. This difference may reflect differential morbidity as well as differential use of sick leave. However, the discrepancy increased steadily until the 6th week before delivery $(21.2 \%)$ and indicated that the difference in sick leave rates is associated with whether job adjustment is obtained or not.

If a large proportion of the employees who quit their original job $(\mathrm{N}=836)$ did so because of ill health, the results would be distorted. Prepregnancy disease and pregnancy complications cause an increase in the risk of sickness absence that is not easily influenced by job adjustment. The exclusion of a large group with such disease or complications would therefore lead to an overestimation of the association between job adjustment and reduced rates of sick leave immediately prior to delivery. However, those who quit did not differ from those who stayed with regard to the proportions reporting prepregnancy chronic illness, sickness absence the year prior to pregnancy or pregnancy complications (bleeding in pregnancy, pre-eclampsia, pelvic pain) (data not shown). It is therefore not likely that the different sick leave rates were due to selection of the study population.

The different sick leave rates between the women needing and obtaining adjustment and those needing but 
Table 3. Need for job adjustment and the proportion of women obtaining adjustment according to work-related factors, education, age and children in household. $(95 \% \mathrm{Cl}=95 \%$ confidence interval, $\mathrm{OR}=$ odds ratio)

\begin{tabular}{|c|c|c|c|c|c|c|c|}
\hline \multirow[t]{2}{*}{ Category } & \multirow[t]{2}{*}{ Number } & \multicolumn{2}{|c|}{$\begin{array}{l}\text { Need for job } \\
\text { adjustment }\end{array}$} & \multirow{2}{*}{$\begin{array}{l}\text { Proportion } \\
\text { obtaining } \\
\text { adjustmenta }\end{array}$} & \multirow[t]{2}{*}{$95 \% \mathrm{Cl}$} & \multirow[t]{2}{*}{$\begin{array}{c}\text { Adjusted } \\
\mathrm{OR}^{\circ}\end{array}$} & \multirow{2}{*}{$\begin{array}{c}95 \% \mathrm{Cl} \\
\text { of adjusted } \\
\text { OR }\end{array}$} \\
\hline & & N & $\%$ & & & & \\
\hline Total & 2713 & 1691 & 62.3 & 55.4 & & & \\
\hline \multicolumn{8}{|l|}{ Size of worksite } \\
\hline $\begin{array}{l}\leq 10 \text { employees } \\
11-50 \text { employees } \\
>50 \text { employees }\end{array}$ & $\begin{array}{l}793 \\
932 \\
963\end{array}$ & $\begin{array}{l}478 \\
585 \\
613\end{array}$ & $\begin{array}{l}60.3 \\
62.8 \\
63.7\end{array}$ & $\begin{array}{l}52.0 \\
53.7 \\
59.2\end{array}$ & $\begin{array}{l}47.5-56.5 \\
49.7-57.7 \\
55.3-63.1\end{array}$ & $\begin{array}{l}1.0 \\
1.2 \\
1.4\end{array}$ & $\begin{array}{l}0.9-1.6 \\
1.0-1.8\end{array}$ \\
\hline \multicolumn{8}{|l|}{ Labor-market sector } \\
\hline $\begin{array}{l}\text { Private } \\
\text { Public } \\
\text { Unknown }\end{array}$ & $\begin{array}{r}850 \\
1057 \\
806\end{array}$ & $\begin{array}{l}533 \\
689 \\
469\end{array}$ & $\begin{array}{l}62.7 \\
65.2 \\
58.2\end{array}$ & $\begin{array}{l}55.5 \\
53.9 \\
57.4\end{array}$ & $\begin{array}{l}51.3-59.7 \\
50.2-57.6 \\
52.9-66.9\end{array}$ & $\begin{array}{l}1.0 \\
0.8 \\
1.1\end{array}$ & $\begin{array}{l}0.6-1.1 \\
0.8-1.4\end{array}$ \\
\hline \multicolumn{8}{|l|}{ Gender of co-workers } \\
\hline $\begin{array}{l}\text { Mostly women } \\
\text { Equal } \\
\text { Mostly men }\end{array}$ & $\begin{array}{r}1670 \\
521 \\
399\end{array}$ & $\begin{array}{r}1138 \\
265 \\
227\end{array}$ & $\begin{array}{l}68.1 \\
50.9 \\
56.9\end{array}$ & $\begin{array}{l}56.2 \\
57.7 \\
52.9\end{array}$ & $\begin{array}{l}53.3-59.1 \\
51.7-63.7 \\
46.4-59.4\end{array}$ & $\begin{array}{l}1.0 \\
1.0 \\
0.8\end{array}$ & $\begin{array}{l}0.8-1.4 \\
0.6-1.1\end{array}$ \\
\hline \multicolumn{8}{|l|}{ Educational level } \\
\hline $\begin{array}{l}\text { Primary school } \\
\text { Secondary }(9-10 \text { years) } \\
\text { Secondary ( } 11-12 \text { years) } \\
\text { University or college }\end{array}$ & $\begin{array}{r}228 \\
419 \\
1059 \\
945\end{array}$ & $\begin{array}{l}172 \\
267 \\
637 \\
576\end{array}$ & $\begin{array}{l}75.4 \\
63.7 \\
60.2 \\
61.0\end{array}$ & $\begin{array}{l}52.3 \\
51.3 \\
56.8 \\
56.1\end{array}$ & $\begin{array}{l}44.8-59.8 \\
45.0-57.3 \\
52.9-60.7 \\
52.6-60.2\end{array}$ & $\begin{array}{l}1.0 \\
0.9 \\
1.0 \\
1.2\end{array}$ & $\begin{array}{l}0.6-1.4 \\
0.6-1.3 \\
0.7-1.6\end{array}$ \\
\hline \multicolumn{8}{|l|}{ Work schedule } \\
\hline $\begin{array}{l}\text { Daytime work } \\
\text { Shift work } \\
\text { Other work schedules }\end{array}$ & $\begin{array}{r}1804 \\
465 \\
422\end{array}$ & $\begin{array}{r}1010 \\
368 \\
300\end{array}$ & $\begin{array}{l}56.0 \\
79.1 \\
71.1\end{array}$ & $\begin{array}{l}57.3 \\
61.4 \\
41.3\end{array}$ & $\begin{array}{l}54.2-60.4 \\
56.4-66.9 \\
37.5-46.0\end{array}$ & $\begin{array}{l}1.0 \\
1.2 \\
0.5\end{array}$ & $\begin{array}{l}0.9-1.6 \\
0.4-0.7\end{array}$ \\
\hline \multicolumn{8}{|l|}{ Weekly workhours } \\
\hline $\begin{array}{l}\geq 35^{\mathrm{c}} \\
<35\end{array}$ & $\begin{array}{r}1689 \\
912\end{array}$ & $\begin{array}{r}1063 \\
547\end{array}$ & $\begin{array}{l}63.0 \\
60.0\end{array}$ & $\begin{array}{l}59.5 \\
49.2\end{array}$ & $\begin{array}{l}56.5-62.5 \\
45.0-53.4\end{array}$ & $\begin{array}{l}1.0 \\
0.9\end{array}$ & $0.7-1.1$ \\
\hline \multicolumn{8}{|l|}{ Children $<16$ years } \\
\hline $\begin{array}{l}\text { Noc } \\
\text { Yes }\end{array}$ & $\begin{array}{l}1288 \\
1359\end{array}$ & $\begin{array}{l}814 \\
829\end{array}$ & $\begin{array}{l}63.1 \\
61.0\end{array}$ & $\begin{array}{l}61.4 \\
49.6\end{array}$ & $\begin{array}{l}58.1-64.7 \\
46.2-53.0\end{array}$ & $\begin{array}{l}1.0 \\
0.8\end{array}$ & $0.6-1.0$ \\
\hline \multicolumn{8}{|l|}{ Age (years) } \\
\hline $\begin{array}{l}<25^{6} \\
25-29 \\
\geq 30\end{array}$ & $\begin{array}{r}634 \\
1077 \\
1002\end{array}$ & $\begin{array}{l}450 \\
669 \\
572\end{array}$ & $\begin{array}{l}71.0 \\
62.1 \\
57.1\end{array}$ & $\begin{array}{l}58.4 \\
57.4 \\
50.5\end{array}$ & $\begin{array}{l}53.8-63.0 \\
53.7-61.1 \\
46.4-54.6\end{array}$ & $\begin{array}{l}1.0 \\
1.0 \\
0.8\end{array}$ & $\begin{array}{l}0.7-1.3 \\
0.6-1.2\end{array}$ \\
\hline
\end{tabular}

a Adjustments obtained given as the percentage of the number needing adjustment, with $95 \%$ confidence intervals for the estimates.

b Odds ratios for obtaining job adjustment, adjusted for the other variables in the table by logistic regression; 1509 of 1691 cases included in the analyses.

- Category used for reference.

Evening work, night work, and work with no fixed schedule.

not obtaining adjustment could have been a result of a difference in work conditions between the groups, as sick leave varies with levels of strenuous work (5). However, the prevalence of work conditions known to be associated with an increased risk of sickness absence (ie, strenuous work postures, heavy lifting, and shift work) were approximately the same in the 2 groups. Women not obtaining adjustment more often reported a hectic work pace (associated with an increased risk of sick leave), but at the same time more often reported working part-time (associated with a reduced risk for sick leave) (data not shown).

Recall bias might have distorted the results, as both the exposure (adjustment) and outcome (sick leave rate) were reported after the delivery. The finding that the association between job adjustment and sick leave rates remained when information about job adjustment was based on job titles characterized by the answers of the women who did not take sick leave immediately before delivery indicates that the difference in the sick leave rates in our study was not wholly due to recall bias. The division of occupations into groups with high adjustment rates and low adjustment rates did not take into account individual needs for job adjustment. The decreased difference in the sick leave rates might therefore have been a result of misclassification of exposure.

\section{Workplace characteristics and job adjustment}

The larger workplaces had higher adjustment rates than smaller ones in Norway, as was also found in England in 1989 (11). There are 2 possible reasons why larger workplaces have more opportunities to provide job adjustment. There will be more people engaged in similar tasks, and the tasks may be more easily reorganized to meet the transient incompatibility between work and pregnancy. In addition, Norway's Work Environment Act requires more extensive safety organization in larger workplaces. In a study of work environments in Norway 
in 1989 (16), respondents working in workplaces with more than 50 employees reported that the workplace had organized safety work more often than respondents from smaller workplaces. This difference may be associated with a more active attitude towards pregnancy within the larger workplaces. More employees in the public than the private sector reported working in workplaces with safety delegates (16), but the difference was small.

"Other work schedules" exist in both the private and the public sector. A study from the municipal sector in Norway in 1993 revealed a high correlation between such schedules and a lack of regular work contracts (21). This situation may indicate that employees working on such schedules are more vulnerable when it comes to pregnancy-related rights.

This study from Norway did not find, as in France, Italy and England, that job adjustment varied between the public and private sectors of the labor market. The similarity between the sectors in Norway may be a result of an overall similarity in adherence to the Work Environment Act (16).

"Other work schedules", part-time work, and children under 16 years of age in the household were all correlated. The finding that part-time work lost its association with job adjustment in the final model may be due to the fact that most part-time work was "normalized" (22) in Norway in the 1980s (ie, it obtained benefits and rights similar to those of full-time work). This development does not preclude that subgroups of pregnant women working part-time in daytime work or shift work may have more problems in obtaining job adjustment than full-time workers.

The finding that having children in the household was associated with a lower proportion of women obtaining job adjustment may be an expression of a greater need for job adjustment among pregnant mothers, rather than an expression of workplaces withholding job adjustment for this group.

\section{Concluding remarks}

In 1989 in Norway, two-thirds of the pregnant employees were in need of job adjustment, and half of those in need obtained the needed adjustment. A substantial reduction in sickness absence was associated with job being adjusted. This finding suggests that more attention should be paid to conditions at the workplace that hamper or facilitate the fulfillment of legal requirements for job adjustment during pregnancy.

\section{Acknowledgments}

We wish to thank the participants of the study, the midwives who organized the data collection, and Eli Heiberg
Endresen, a co-worker in the study. We are greatly indebted to Anne Grethe Ihlen for typing the manuscript.

The work was supported by the Norwegian Research Council for Science and the Humanities, the Work Environment Fund of the Confederation of the Norwegian Business and Industry, the Borregaard A/S Research Fund, the Ministry of Health and Social Affairs, and the Norwegian National Health Association.

\section{References}

1. Saurel-Cubizolles MJ, Kaminski M. Pregnant women's working conditions and their changes during pregnancy: a national study in France. Br J Ind Med 1987;44:236-43.

2. Conne-Perréard E, Bousquet A. Prescription d'arrêts de travail temporaires aux femmes enceintes en l'absence d'un cadre légal. Rev Epidémiol Santé Publique 1992;40:113--20.

3. Alexanderson $\mathrm{K}$, Hensing G, Lejon $\mathrm{M}$, Akerlind I, Rydh $\mathrm{H}$, Carstensen J, Bjurulf P. Pregnancy related sickness absence in a Swedish county, 1985-87. J Epidemiol Community Health 1994;48(5):464 70 .

4. Toph $\varnothing$ j A. Graviditet og sygefravær [Pregnancy and sickness absence]. Ugeskr Lager 1994;156/34:6359—65.

5. Strand K, Wergeland E, Bjerkedal T. Work load, job control and the risk of leaving work by sickness absence before delivery, Norway 1989. Scand J Soc Med. In press.

6. Alexanderson K, Hensing G, Carstensen J, Bjurulf P. Pregnancy-related sickness absence among employed women in a Swedish county. Scand J Work Environ Health 1995;21:1918.

7. Saurel-Cubizolles MJ, Romito P, Garcia J. Description of maternity rights for working women in France, Italy and in the United Kingdom. Eur J Public Health 1993;3:48-53.

8. Vigerust E. Graviditet, arbeidsmiljø og likestilling [Pregnancy, working conditions and gender equity]. In: Ketschner K, Lindgård J, Nielsen R, editors. Den sociale dimension i kvinderetligt perspektiv [The social dimension in legal gender perspective]. København: Jurist og Økonomforbundets Forlag, 1995:171-92.

9. Mamelle N, Bertucat I, Auray JP, Duru G. Quelles mesures de prévention de la prématurité en milieu professionel? Rev Epidémiol Santé Publique 1986;34:286-93.

10. Romito P, Saurel-Cubizolles MJ. Fair law, unfair practices? Benefiting from protective legislation for pregnant workers in Italy and France. Soc Sci Med 1992;35(12):1485-95.

11. McRae S. Maternity rights in Britain: the PSI report on the experience of women and employers. London: Policy Studies Institute, 1991.

12. Wergeland E, Strand K, Endresen EH. Gravid i Norge ved inngangen til nittiårene [Pregnant in Norway at the entrance of the 1990s]. Oslo: Department of Preventive Medicine, University of Oslo, 1991.

13. Strand K, Wergeland E, Bjerkedal T. Pregnancy and work a national survey Norway 1989: representativity of study sample and responders. Oslo: Department of Preventive Medicine, University of Oslo, 1995.

14. Statistics Norway. Labor market statistics 1989. Oslo: Statistics Norway, 1990.

15. Gardner MJ, Altman DG. Statistics with confidence. London: British Medical Journal \& The University Press Ltd, 1989. 
16. Pape, TC. Arbeidsmiljø i Norge [Working environment in Norway]. Oslo: Institute for Applied Social Science, 1993. Report 149.

17. Hosmer DW, Lemenshow S. Applied logistic regression. New York (NY): John Wiley \& Sons Inc, 1989.

18. SPSS Inc. SPSS/PC + 4.0 The statistical package for IBM PC. Chicago (IL): SPSS Inc, 1990.

19. Strand K, Wergeland E, Bjerkedal T. Fertility patterns according to occupational grouping in Norway, 1989. Scand J Soc Med 1996;24(1):50—4.

20. The work environment act, Norway: act no 4 of Feb 1977 relating to worker protection and working environment with subsequent amendments. Oslo: Grøndahl \& Søn, 1987.

21. Moland LE. De små grå: deltidsarbeid og ansettelsesforhold $\mathrm{i}$ kommunene [Small and grey: part-time work and conditions of appointment in the municipal sector]. Oslo: Institute for Applied Social Science, 1994. Report 171.

22. Ellingsæter AL. Gender, work and social change. Oslo: Institute for Social Research, 1995. Report 14.

Received for publication: 21 November 1996 